\title{
The Impact of Changes in Exhaust Temperature on the Power Output and Heat Rate of a Gas Turbine with a Capacity of $238 \mathrm{MW}$
}

\author{
Hendra Budiono Putra Parapa, 1,a,* \\ ${ }^{1}$ PT PLN (Persero) UPDL Makassar, Jl. Poros Malino, Gowa, 92119, Indonesia \\ a, ${ }^{*}$ hendra.budiono@pln.co.id (Corresponding author)
}

\begin{abstract}
The exhaust temperature parameter is one of the parameters that need to be considered in maintaining the performance of the gas turbine. The purpose of this study is to analyze the effect of changes in exhaust temperature on power output and heat rate. The data used is the actual design data of the M701 gas turbine. This data is used in building the model using the GateCycle software. The modeling simulation results are then validated using the actual design data. To see the impact of changes in exhaust temperature, data from the latest gas turbine performance results are used. This study concludes that changes in exhaust temperature parameters of $1^{\circ} \mathrm{C}$ have an impact on changes in power output of $0.273 \%$ and heat rate of $0.047 \%$.
\end{abstract}

\section{Keywords-Exhaust Temperature; Power Output; Heat Rate}

\section{Introduction}

PLN as a provider of electricity supply in Indonesia uses several types of thermal generators, one of them is the Gas Turbine Power Plant which uses a gas turbine. The gas turbines currently used by PLN have various capacities, ranging from capacities below $50 \mathrm{MW}$ to capacities above $200 \mathrm{MW}$ per unit. The use of gas turbines at PLN is generally as a peaker unit, where the gas turbine unit has a fast response if fluctuations occur in the system. Therefore, the performance of the gas turbine actually needs to be considered, considering that, its function is quite crucial in the PLN system. One of the operating parameters that need to be considered in the operation of a gas turbine is the exhaust temperature.

The exhaust temperature parameter in gas turbine operation is used as a temperature controller and trip temperature protection. There are two factors that influence the exhaust temperature parameter in gas turbine operation in terms of efficiency and the resulting power output, namely the compressor pressure ratio and turbine inlet temperature (TIT) [1]. The cause of the increase in exhaust temperature can be caused by an increase in the ambient temperature and humidity as well as an increase in the amount of fuel used [2]. In previous studies, an evaluation of the impact of ambient temperature on the thermal efficiency of the cycle was carried out by $54.159 \%$ at $24{ }^{\circ} \mathrm{C}$ ambient temperature and $49.727 \%$ at $33{ }^{\circ} \mathrm{C}$ ambient temperature for Centaur 40 gas turbine [3]. In addition, a study has also been carried out regarding the impact of fuel variations on the performance of the GE 6FA model gas turbine, where when using natural gas, the efficiency increases from 35.05 to $35.39 \%$, when using syngas the efficiency increases from 35.44 to $35.73 \%$ and using aviation kerosene, the efficiency increased from 35.36 to $35.41 \%$ [4].

In other studies related to comparative studies of gas turbine performance with fuel variations, namely crude oil, natural gas, and synthesis gas, the results of natural gas are obtained as the optimal choice for fuel with an increase in efficiency of about $3.12 \%$ for the GE Frame $9 \mathrm{E}$ gas turbine [5] and the effect of a decrease in the exhaust temperature of the gas turbine on the performance of the Muara Tawar combined cycle, where a decrease in the exhaust temperature of $2{ }^{\circ} \mathrm{C}$ will reduce the power output of the steam turbine of $0.787 \%$ [6]. 
Besides, a gas turbine performance analysis was also carried out using different compressor configurations [7]. Studies related to the impact of changes in exhaust temperature on the power output and heat rate of gas turbines have not been widely carried out. Therefore, a study of this research was conducted.

This study aims to analyze the effect of changes in exhaust temperature on power output and heat rate. The parameter used in the evaluation is the exhaust temperature. The case study used in this research is the M701F gas turbine with a capacity of $238 \mathrm{MW}$. The basis for selecting the M701F gas turbine in this case study is because this gas turbine model is the highest class of gas turbine currently used by PLN and has a simple cycle efficiency of $39.9 \%$ (ISO Condition). By conducting this research, it can be seen the impact caused by changes in exhaust temperature parameters on the performance of the gas turbine by looking at the percentage changes in the generated power output and the heat rate caused.

The working principle of a gas turbine uses the Bryton Cycle, where in general, the processes that occur in a gas turbine system are as follows:

1. Compression of air is sucked in and compressed.

2. Combustion of fuel is mixed into the combustion chamber with air and then burned.

3. Expansion of combustion gases expands and flows out through the nozzle

4. Exhaust gases from combustion are removed through the exhaust duct.

The representation of the gas turbine cycle can be seen in the temperature-entropy diagram as shown in figure 1 and figure 2, which describes the thermodynamic process that occurs.

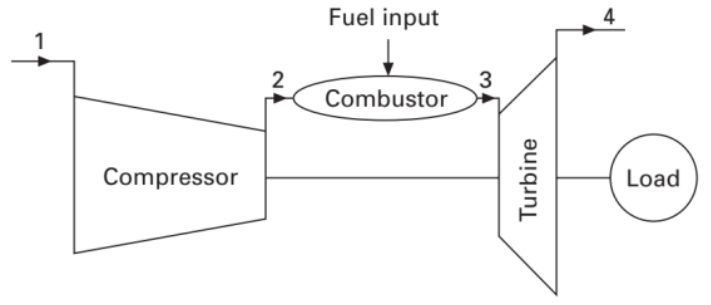

Figure 1. Gas turbine simple cycle

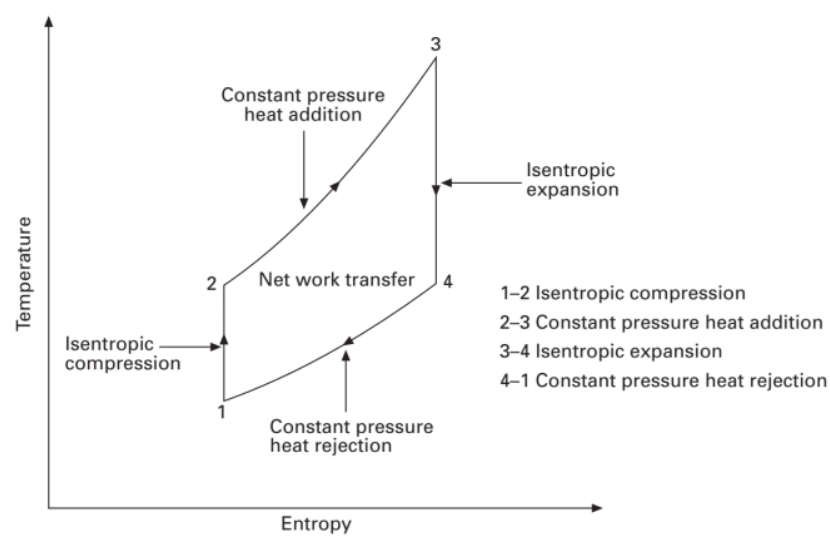

Figure 2. Representation of gas turbine cycle on temperatureentropy diagram [8]

From figure 1 and 2, the work of adiabatic compression can be shown by the equation:

$W_{12}=C_{p}\left(T_{2}-T_{1}\right)$

And the equation for the compressor discharge temperature $\mathrm{T}_{2}$ for isentropic compression is

$T_{2}=T_{1}\left(\frac{P_{2}}{P_{1}}\right)^{\frac{\gamma-1}{\gamma}}$

Where $\gamma$ is the specific heat ratio of the gas $(\mathrm{cp} / \mathrm{cv})$ and is known as the isentropic index, and $\mathrm{cv}$ is the specific heat at constant volume.

For the work equation for adiabatic expansion and exhaust temperature $\mathrm{T}_{4}$, it is shown by the equation:

$W_{34}=C_{p}\left(T_{3}-T_{4}\right)$

And,

$T_{4}=T_{3}\left(\frac{P_{4}}{P_{3}}\right)^{\frac{\gamma-1}{\gamma}}$

As for the heat input, it is shown by the equation:

$Q_{23}=C_{p}\left(T_{3}-T_{2}\right)$

For the net cycle work per unit mass flow rate, which is the difference between the work of expansion and compression, it can be shown by the equation:

$W_{\text {net }}=C_{p}\left(T_{3}-T_{4}\right)-C_{p}\left(T_{2}-T_{1}\right)$

So it can be seen the thermal efficiency $\eta_{\text {th }}$, which is the ratio between net cycle work and heat input. This can be written in the equation:

$\eta_{t h}=\frac{W_{n e t}}{Q_{23}}$

Or

$\eta_{t h}=1-\frac{T_{4}-T_{1}}{T_{3}-T_{2}}$ 


\section{Research Methodology}

The following is a description of the method used to analyze the effect of changes in exhaust temperature parameters on the power output and heat rate of gas turbines. As a case study, this research uses actual design data from the M701F gas turbine. The actual design data is used in modeling using the Gatecycle software. The simulation results parameters are then validated according to the actual design parameters, then followed by off design modeling, where in this condition the exhaust temperature parameters will be varied to see the impact on the power output and heat rate. In this simulation the condition of the ambient environmental parameters and properties as well as the calorific value of the gas are considered constant. The steps in conducting this research can be seen in Figure 3.

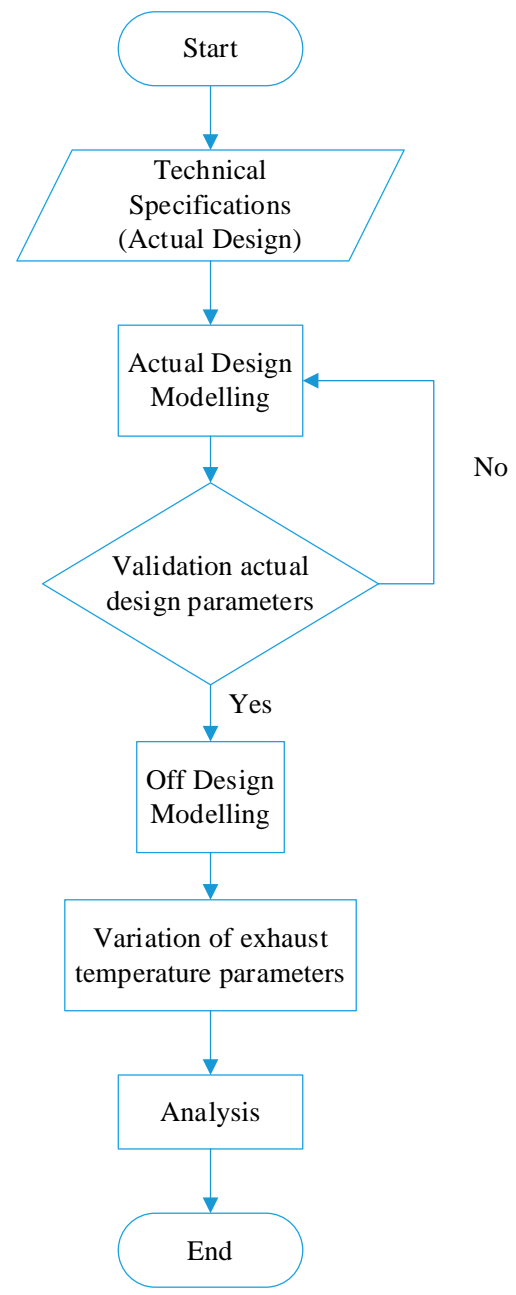

Figure 3. Flowchart Research

\section{Results and Discussion}

The simulation model of the M701F gas turbine using the Gatecycle software can be seen in figure 4 . From the simulation results, validation is carried out based on the actual design data of the M701F gas turbine.

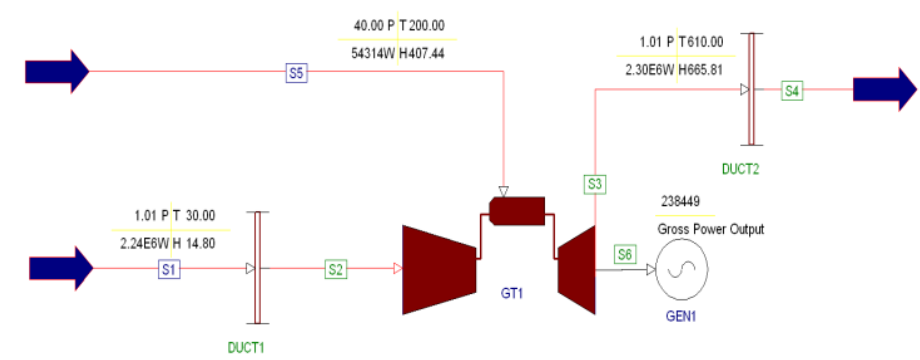

Figure 4. M701F gas turbine model in Gatecycle software

Legend information of figure 4 :

S1 (Stream 1) : Environmental air that enters the gas turbine is sucked by the compressor

Duct1 : Air delivery to the compressor

GT1 : The type of gas turbine used, in this case the case study model is M701F

S3 (Stream 3) : Exhaust air duct from gas turbine

Duct 2 : Distribution of exhaust air to the environment

S5 (Stream 5) : The fuel line that enters the gas turbine

GEN1 : Generator

$\mathrm{P} \quad$ : Pressure (bar)

$\mathrm{T} \quad$ : Temperature (OC)

W : Mass flow rate $(\mathrm{kg} / \mathrm{h})$

$\mathrm{H} \quad$ : Enthalpy $(\mathrm{kJ} / \mathrm{kg})$

Based on the validation results shown in table 1, the lowest deviation is in the exhaust temperature parameter which is $0.00 \%$ while the highest deviation is in the fuel gas mass flow which is $0.581 \%$. However, the deviation of these parameters is still within the tolerance limit of $2 \%$ for critical parameters based on ANSI/ISA-S77.20 [9].

Table 1. Comparison between simulation results and actual design 


\begin{tabular}{lcrrr}
\hline \multicolumn{1}{c}{ Parameter } & Unit & $\begin{array}{r}\text { Actual } \\
\text { Design }\end{array}$ & $\begin{array}{c}\text { Simulation } \\
\text { Result }\end{array}$ & $\begin{array}{c}\text { Deviation } \\
(\%)\end{array}$ \\
\hline $\begin{array}{l}\text { Gross } \\
\text { Power } \\
\begin{array}{l}\text { Output } \\
\text { Gross Heat }\end{array}\end{array}$ & $\mathrm{kW}$ & 238500 & 238449 & $-0,021$ \\
$\begin{array}{l}\text { Rate (LHV } \\
\text { Basis) }\end{array}$ & $\mathrm{kJ} / \mathrm{kWh}$ & 9894 & 9873,84 & $-0,204$ \\
$\begin{array}{l}\text { Exhaust } \\
\text { Temperature } \\
\text { Fuel Gas } \\
\text { Mass Flow }\end{array}$ & $\mathrm{o} \mathrm{C}$ & 610 & 610 & 0,000 \\
\hline
\end{tabular}

After validating the actual design parameters, then proceed with off design simulation, where at this stage the exhaust temperature variation is carried out which aims to see the impact caused by changes in exhaust temperature on the power output and heat rate of the gas turbine. Variations in exhaust temperature are carried out starting from temperatures of $567-608^{\circ} \mathrm{C}$, this temperature variation is carried out based on the latest performance test data.

The simulation results of the impact of changes in exhaust temperature on the power output and heat rate of the M701F gas turbine can be seen in Figures 5 and 6 . From Figures 5 and 6 , the temperature variation is carried out by $2^{\circ} \mathrm{C}$ in the temperature range of $567-$ $608^{\circ} \mathrm{C}$.

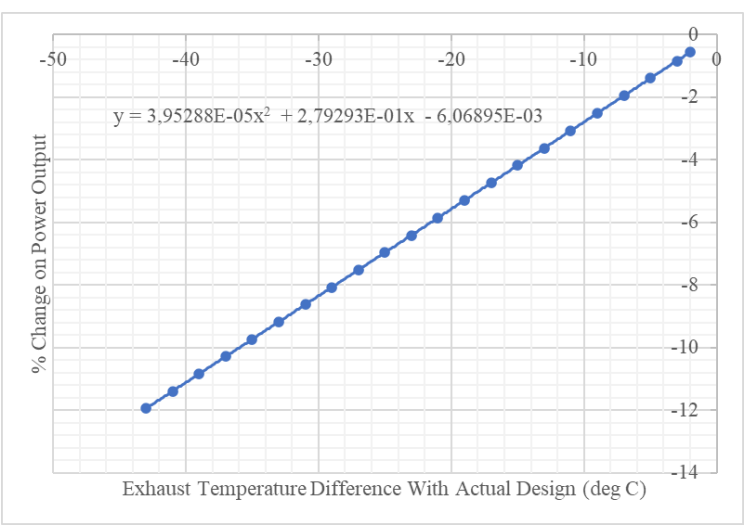

Figure 5. Impact of changes in exhaust temperature on power output

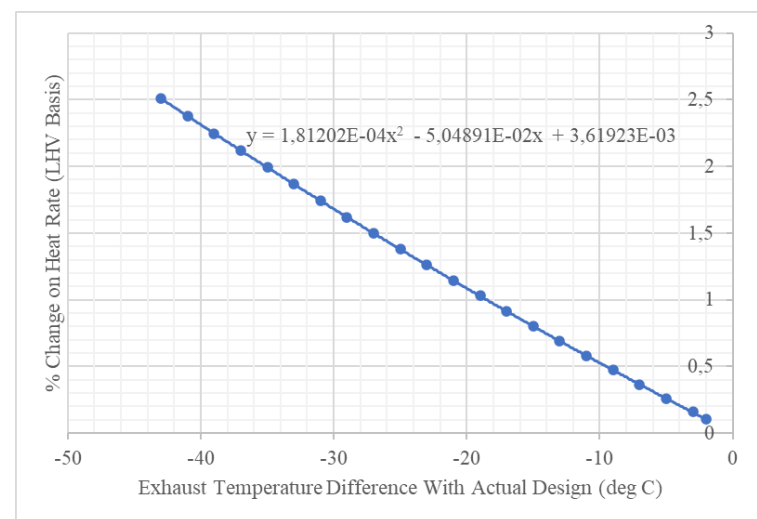

Figure 6. Impact of changes in exhaust temperature on heat rate

Based on figure 5 , a change in exhaust temperature of $1^{\mathrm{O}} \mathrm{C}$ has an impact on decreasing the power output by $0.273 \%$, while in figure 6 , a change in exhaust temperature of $1 \mathrm{OC}$ has an impact on increasing the heat rate by $0.047 \%$. Thus, from Figures 5 and 6 it can be seen that the exhaust temperature parameter contributes to influencing the power output and heat rate of the M701F gas turbine.

\section{Conclusion}

Based on the results and discussion, it can be concluded that the exhaust temperature parameter simulation results show that a change in the exhaust temperature parameter of $1 \mathrm{OC}$ has a decrease in the power output of $0.273 \%$ and an increase in heat rate of $0.047 \%$.

\section{References}

[1] M. P. Boyce, Gas Turbine Engineering Handbook Fourth edition. 2012.

[2] T. K. Ibrahim, M. M. Rahman, O. M. Ali, F. Basrawi, and R. Mamat, "Optimum performance enhancing strategies of the gas turbine based on the effective temperatures," MATEC Web Conf., Vol. 38, January, 2016, doi: 10.1051/matecconf/20163801002.

[3] M. Adib, P. M. Santika, and J. V. Tuapetel, "Analisis Pengaruh Ambient Temperature Terhadap Daya Turbin Gas Tipe Centaur 40 di Lapangan Produksi Sepinggan , Chevron Indonesia Company", (Analysis of the Effect of Ambient Temperature on the Power of the Centaur 40 Gas Turbine at the Sepinggan Production Field, Chevron Indonesia Company), Jurnal Teknik Mesin ITI, Vol. 3, No. 2, pp. 2934, 2019.

[4] G. Marin, D. Mendeleev, B. Osipov, and A. Akhmetshin, 


\section{INTEK Jurnal Penelitian}

"Study of the effect of fuel temperature on gas turbine performance," E3S Web Conf., Vol. 178, pp. 0-4, 2020, doi: 10.1051/e3sconf/202017801033.

[5] H. J. Kadhim, T. J. Kadhim, and M. H. Alhwayzee, "A Comparative Study of Performance of Al-Khairat Gas Turbine Power Plant for Different Types of Fuel," IOP Conf. Ser. Mater. Sci. Eng., Vol. 671, No. 1, 2020, doi: 10.1088/1757-899X/671/1/012015.

[6] Muchlisin, N. Darmawan, and S. Budi, "The Effect of Decreasing Gas Turbine Flue Gas Temperature on The Performance of Muara Tawar Combined Cycle Power Plant," IOP Conf. Ser. Mater. Sci. Eng., Vol. 1096, No. 1, p. 012112, 2021, doi: 10.1088/1757-899x/1096/1/012112.

[7] A. Almutairi, M. Zedan, H. M. Alhajeri, and A. Alenezi, "Thermal performance analysis of gas turbine engines based on different compressor configurations," Heat Transf., Vol. 49, No. 5, pp. 2717-2745, 2020, doi: 10.1002/htj.21742.

[8] A. M. Y. Razak, Industrial gas turbines: Performance and operability. Elsevier. 2007.

[9] A. N. Standard, Fossil Fuel Power Plant Simulators -, May. 1994 (https://www.isa.org/). 